\title{
INVERTED, 'PARALLEL' ACCRETION OF ORGANIC MATERIAL IN THE CAVE SETERGROTTA, RANA, NORTHERN NORWAY: A CASE STUDY
}

\section{OBRNJENE 'PARALELNE’ AKRECIJE ORGANSKEGA MATERIALA V JAMI SETERGOTTA, RANA, SEVERNA NORVEŠKA: ŠTUDIJSKI PRIMER}

\author{
Dagfinn MOE$^{1}$, Stein-Erik LAURITZEN ${ }^{2} \&$ Rannveig Øvrevik SKOGLUND
}

\begin{abstract}
UDC 551.435.84:581.33(481.7)

Dagfinn Moe, Stein-Erik Lauritzen \& Rannveig Øvrevik Skoglund: Inverted, 'parallel' accretion of organic material in the cave Setergrotta, Rana, northern Norway: a case study

The occurrence of an upside-down parallel accretion of organic gyttja, about $10 \mathrm{~cm}$ in thickness is reported from the ceiling of an overflow passage in Setergrotta cave, Mo-i-Rana, northern Norway. The deposition process depended on seasonal flooding, was ${ }^{14} \mathrm{C}$ dated back to c. $6500 \mathrm{cal}$. BC $(7645 \pm 115 \mathrm{BP})$. Two pollen diagrams are presented, one from the accretion and one of a nearby minerogenic cave floor deposit. In the accretion sequence, pollen of spruce (Picea abies) was found only in the youngest parts and corresponds to what is known from vegetation historical studies in the region. No significant signals of neither of known vegetation changes caused by climate nor human impact are found in the parallel accretion, contrary to the floor deposit. One of them indicates a marked deforestation dated to about $790 \mathrm{cal}$. BC in the catchment area for the cave pollen/water supply.

Key words: Pollen analysis, ${ }^{14} \mathrm{C}$ date, inverted parallel cave accretion.
\end{abstract}

\begin{abstract}
Izvleček
UDK 551.435.84:581.33(481.7)

Dagfinn Moe, Stein-Erik Lauritzen \& Rannveig Øvrevik Skoglund: Obrnjene 'paralelne' akrecije organskega materiala $v$ Jami Setergotta, Rana, severna Norveška: študijski primer

$\mathrm{V}$ članku poročamo o obrnjenih, do $10 \mathrm{~cm}$ debelih, paralelnih akrecijah organskega sedimenta (gyttja) v prelivnem rovu jame Settergrotta, Moi-i-Rana, severna Norveška. Odlaganje tega sedimenta je bilo vezano na sezonsko poplavljanje rova. ${ }^{14} \mathrm{C}$ datacije so določili največjo starost $6500 \mathrm{cal}$. BC (7645 $\pm 115 \mathrm{BP})$. Primerjamo tudi pelodna diagrama iz akrecije $\mathrm{z}$ diagramom minerogenih sedimentov na jamskih tleh. V zaporedju akrecije smo pelode smreke (Picea abies) našli le v najmlajšem delu, kar ustreza ugotovitvam zgodovinskih študij vegetacije $\mathrm{v}$ regiji. $\mathrm{V}$ akrecijah nismo našli nobenih pomembnih znakov vegetacijskih sprememb, ki bi jih povzročile klimatske spremembe ali človek. Drugače je v minerogenem sedimentu na jamskih tleh, kjer pelodna analiza kaže na deforestacijo v času 790 cal. BC v zbirnem območju peloda.

Ključne besede: Pelodna analiza, ${ }^{14} \mathrm{C}$ datiranje, obrnjene paralelne akrecije.
\end{abstract}

\section{INTRODUCTION}

Active conduits in karst caves are extremely efficient conveyors for groundwater, although the flow velocity in individual passages depends on the internal "plumbing" of the system and on the temporal hydrological flood conditions. Due to the branched nature of cave passages and relatively large passage cross-sections, the velocity of water in the phreatic zone is much less than the velocity in corresponding vadose (canyon) passages and

\footnotetext{
${ }^{1}$ Natural History Collection, University of Bergen; fax: +4755589667; e-mail: Dagfinn.Moe@um.uib.no

${ }^{2}$ Department of Earth Science, University of Bergen; fax: +475583660; e-mail: Stein.Lauritzen@geo.uib.no

${ }^{3}$ Department of Geography, University of Bergen; fax: +475583660; e-mail: Rannveig.Skoglund@geog.uib.no

Received/Prejeto: 24.09.2015
} 
surface streams. For these reasons, sections of phreatic passage (sumps or phreatic loops) act as sediment traps while stream ways act as conveyors. Large underground voids act as settling tanks, so that only the smallest fractions may become conveyed through a karst system (Ford \& Williams 2007). The same effect takes place in stagnant annexes for overflow passages where seasonal standstill may allow to settle (systéme annexe) (Mangin 1975; Atkinson 1985). The finest clay particles may, due to electrostatic forces, settle on all available surfaces independent of gravity. This process leads to a laminated clay veneer, or draping, that covers all available surfaces which were submerged in water. In caves, the phenomenon is named parallel accretion and was first described by Reams (1968). Cave divers often encounter this kind of sedimentation in stagnant sections and name such passages 'silted sumps. This paper describes parallel accretion by organic transported debris, which will have particles of approximately neutral buoyancy in water. Organic sediments may also be dated by palynology and radiocarbon and may therefore provide information on timing and rate of the process.

The source area for the organic material may differ; primary particles are possible as well as material from erosion outside or inside the cave. Depending on which transport has taken place, by wind, animals entering the cave or water flow, also a differentiation of particles is possible from place to place and also within the same deposition (e.g. Bui-Thi-Mai 1974, 1988; Lauritzen et al.
1990; Navarro et al. 2000, 2001; Østbye et al. 2006). For these reasons, organic cave deposits of this type may be questionable to use without proper care in palaeoecological studies (e.g. Navarro et al. 2001).

As a part of a cave research program in northern Norway (Lauritzen et al. 2005) parallel accretion was found in Setergrotta (cave = grotte/grotten (Norwegian)), in Rana, northern Norway. An inverted deposition of organic material was attached upside down onto a nearly horizontal ceiling in a cave hall. The thickness of the sediment varied from $1 \mathrm{~cm}$ to about $10 \mathrm{~cm}$. Some sections of the attached layer had become detached and fallen off, so that the ceiling displayed an uneven surface, in part exposing the internal stratigraphy in the remaining lumps.

The pollen transport into the cave system follows the waterway either floating on the surface or within the water together with debris. In period with no water small pollen and charcoal fragment may also wind transport are possible. Two sections about $250 \mathrm{~m}$ from the main entrance were investigated by pollen analysis. The first one a $10 \mathrm{~cm}$ long upside-down ceiling deposit, second, a $75 \mathrm{~cm}$ deep sediment section from the floor of the same passage, a few meters away from the first site.

Three questions are of general interest concerning the parallel accretion: (1) are the deposits of primary or secondary character; (2) what is the age of the parallel accretion and also the age of the neighbouring minerogenic deposit; and (3) does the deposition give palaeoecological information?

\section{DESCRIPTION OF THE AREA}

Setergrotta is part of the Grønli-Seter cave system which is situated about $10 \mathrm{~km}$ north of Mo i Rana municipality in Nordland County (Fig. 1). The cave system comprises 4 caves and more than $8 \mathrm{~km}$ of cave passages (Øvrevik 2002; Skutlaberg 2003; Hestangen 2005; Skoglund \& Lauritzen 2013). These are karst caves formed by dissolution of marble by subsurface water flow through fractured rock. The cave system is situated in a calcite marble which is part of the Uppermost Allochthon (Rødingsfell Nappe Complex) in the Caledonian Orogen (Stephens et al. 1985; Søvegjarto et al. 1989).

The cave system is situated in the eastern hill side of Rauvassdalen valley. The Strokkbekken stream is a tributary stream to the Rauvassåga River and drains an area of about $7 \mathrm{~km}^{2}$, mainly elevated between 250 and $540 \mathrm{~m}$ above sea level. A stream sink in a surface channel of Strokkbekken (approximately $250 \mathrm{~m}$ above sea level) diverts parts of the water flow underground through
Grønligrotta and Setergrotta and towards a spring pool in the valley bottom (approximately $50 \mathrm{~m}$ above sea level) (St. Pierre 1988; Skoglund \& Lauritzen 2013). The total length of the underground water path is estimated to about $2750 \mathrm{~m}$ (Skoglund \& Lauritzen 2013). This has been named an invasion aquifer by Skoglund and Lauritzen (2013), because the cave system (as such) has been developed in a setting strongly influenced by subglacial drainage during the glaciations, while the present cave stream is controlled by gravity, surface topography and the present climate.

Setergrotta is situated close to the valley bottom and cave passages located below the valley bottom are submerged, i.e. they form a series of phreatic loops separated by short vadose stream sections. This cave consists of a series of large halls which has partly suffered from collapse and choking of sediments. This is a probable cause for one of the submerged sections to 

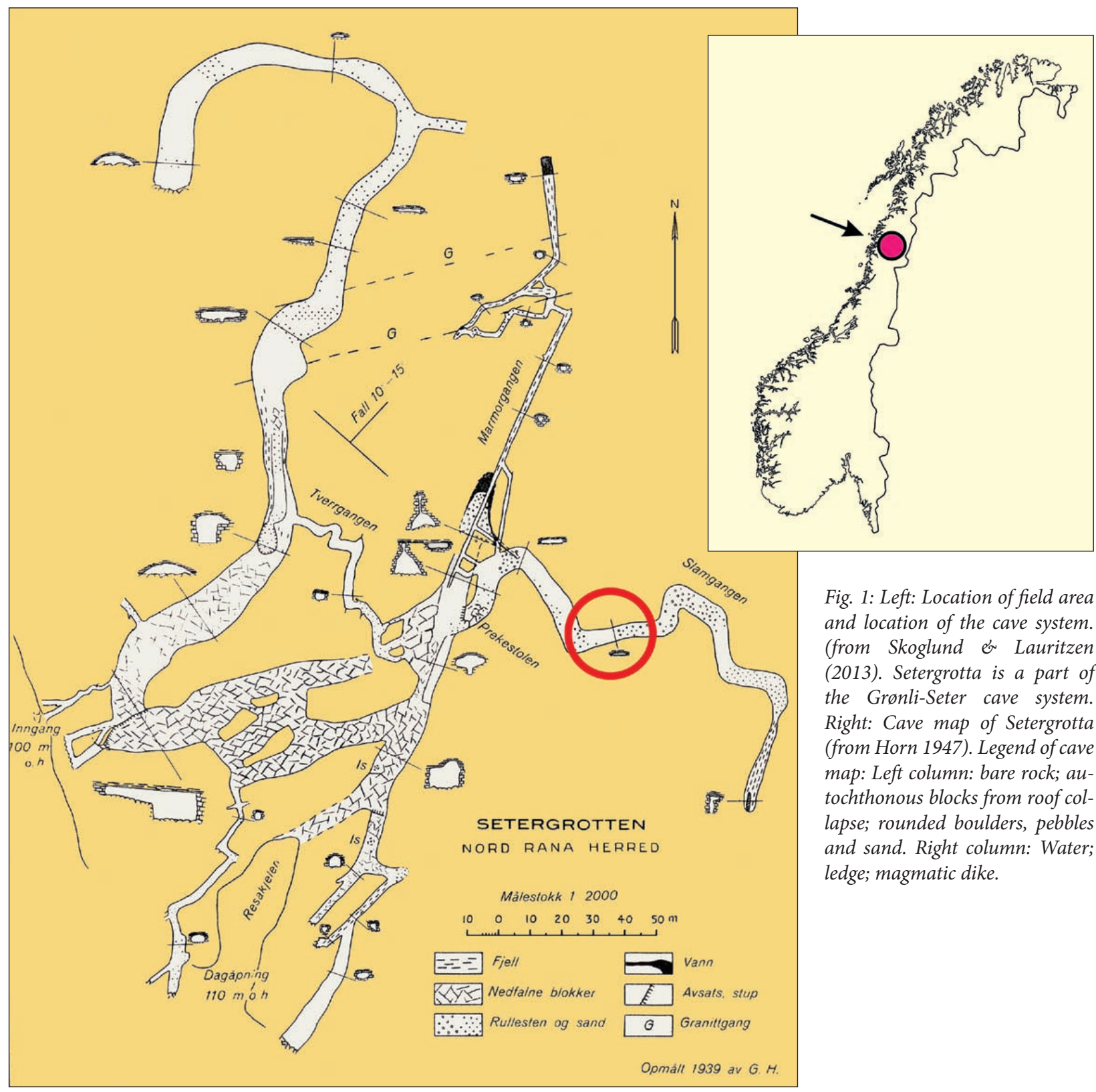

Fig. 1: Left: Location of field area and location of the cave system. (from Skoglund \& Lauritzen (2013). Setergrotta is a part of the Grønli-Seter cave system. Right: Cave map of Setergrotta (from Horn 1947). Legend of cave map: Left column: bare rock; autochthonous blocks from roof collapse; rounded boulders, pebbles and sand. Right column: Water; ledge; magmatic dike.

be under fit for flood discharges. Consequently, during flooding the water level upstream of the constriction rises by up to $11 \mathrm{~m}$ before an overflow path is established through the passages of the Slamgang ("the mud passage") and the Marmorgang ("the marble passage"). As the names indicate, the rising segment of the Slamgang is covered and partly filled with fine sediments, giving it a dirty look. This section forms a stagnant annex except when an overflow towards the Marmorgang occurs. The Marmorgang, the downstream segment of the flood passage, on the other hand, is clean and bright because water always flows here and fine sediments never settle.
The climate in Rana is subarctic, oceanic with cool summers and mild winters and significant precipitation in all seasons. The mean annual temperature in the field area is about $2{ }^{\circ} \mathrm{C}$ dependent on elevation and micro-climatic settings (http:www.senorge.no). The mean annual precipitation in the field area is in the range of 1500-2000 mm/year (http:www.senorge.no) with a regional drainage intensity of $20-80 \mathrm{l} \mathrm{s}^{-1} \mathrm{~km}^{-2}$ (NVE, 2002). Spring flood due to snow melt is the most prolonged flooding event. However, rainstorm events cause floods in the system in all seasons but are most frequent during autumn and winter (Skoglund \& Lauritzen 2013). Flood discharges in the cave stream exceed $1 \mathrm{~m}^{3} \mathrm{~s}^{-1}$ annually, 
and discharges in this range are likely to provide water flow in the floodwater passage of the Slamgang and the Marmorgang. Dirty footprints in Marmorgang passage appear to be washed away several times a year.

The Holocene vegetation history in this part of the region is only partly studied: Loc. 13. Hammarnesset, Rana (UTM VP570633); loc. 14 Storbekken, Rana, (UTM VP736546); loc. 15. Storforshei, Rana (UTM VP791643) (Mørkved 1987). The present day vegetation in the main valley and close to the site (around $200 \mathrm{~m}$ a.s.l.) is dominated by patchy forest, (Norwegian spruce (Picea abies), birch (Betula pubescens), grey alder (Alnus incana), willow species (Salix spp.), and bird cherry (Prunus padus), in addition to more open grassland. Most of the vegetation is disturbed by human activity. With changing exposure, the tree line changes from less than $350-380 \mathrm{~m}$ to around $500 \mathrm{~m}$.

\section{METHOD}

Pollen analysis. The fieldwork was made in 1987. The parallel accretion in Setergrotta is deposited onto, and underneath, a nearly smooth and horizontal mica schist roof, with a slope of approximately $1 / 40$. The deposition covers about $20-30 \mathrm{~m}^{2}$, perhaps more, changing in thickness from a few $\mathrm{mm}$ to around $10 \mathrm{~cm}$. One main reason for the change in thickness is that different parts with different thickness of the deposit have become detached and fallen down to the floor. For the parallel accretion a broad knife was used to cut a 10 by $10 \mathrm{~cm}$ vertical section from the roof accumulation. For this section subsampling was made at the laboratory. For the cave floor deposit, $22 \mathrm{sub}$ samples were made, from the top-level down to the base of the section. The pollen samples were treated for pol- len analysis, following standard laboratory techniques in Fægri \& Iversen (1989).

The accretion deposit was dominated by fragments of ligneous and herbaceous plants, < c. $2 \mathrm{~mm}-\mathrm{c}$. $1 / 10 \mathrm{~mm}>$, in addition to smaller particles $(<1 / 10 \mathrm{~mm})$ (Ditritus granosus (c. 3/4) and Limus detrituosus (c. 1/4). The minerogenic content was very low (Argilla granosa + ) (Troels-Smith 1955). The pollen preservation was fairly good; however, some tendency of oxidation of the pollen was seen. The cave floor sediment consisted of more minerogenic particles, so that HF-preparations were needed. Again the pollen preservation was fairly good.

The chronozones of Mangerud et al. (1974) and local pollen assemblage zones (PAZ) were used.

\section{RESULTS}

Radiocarbon datings. Two radiocarbon dates are made from the locality, one from the parallel accretion, and one from the top layer of the minerogenic floor deposit in the tunnel (Tab. 1). The results are presented in Fig. 2. In general, samples for dating fluvial cave deposits need to be handled with care, since transport and deposition are uncertain and most variable. The dates, therefore, also need to be used with great care; even in our case, when only one small piece of unidentified wood is used.
The results of the pollen analysis are presented in Fig. 2 and 3 using the Core-data program (University of Bergen). The good state of preservation and the low content of minerogenic elements both indicate relatively smooth and also humid conditions during the parallel accretion processes. Also the fact that the deposits have been hanging upside down during millennia's indicate relatively uniform and smooth conditions with a minimum of erosion.

Tab. 1: Radiocarbon datings from the cave Setergrotta (Abbr. T= Trondheim, Norway; TUa= Trondheim /Uppsala). BC/AD calibration is in according to'IntCal13' (Reimer et al. 2013).

\begin{tabular}{l|l|l|l|l|l}
\hline Type of material & Level & $\begin{array}{l}\text { Callibrated age, } \\
2 \text { sigma }\end{array}$ & Age BP(1950) & Lab. No & Sample \\
\hline Parallel accretion: & $0.5-1.0 \mathrm{~cm}$ below roof & $\begin{array}{l}6752 / 6720- \\
6709 / 6236 \mathrm{BC}\end{array}$ & $7645+115$ & TUa-79 & wood \\
\hline \multicolumn{7}{|l|}{} & \multicolumn{5}{|l}{$536 / 528-522 / 46 \mathrm{BC}$} & $2240+90$ & T-6356A & $\begin{array}{l}\text { Bulk } \\
\text { sediment }\end{array}$ \\
\hline
\end{tabular}


INVERTED, 'PARALLEL' ACCRETION OF ORGANIC MATERIAL IN THE CAVE SETERGROTTA, RANA, NORTHERN NORWAY: ...

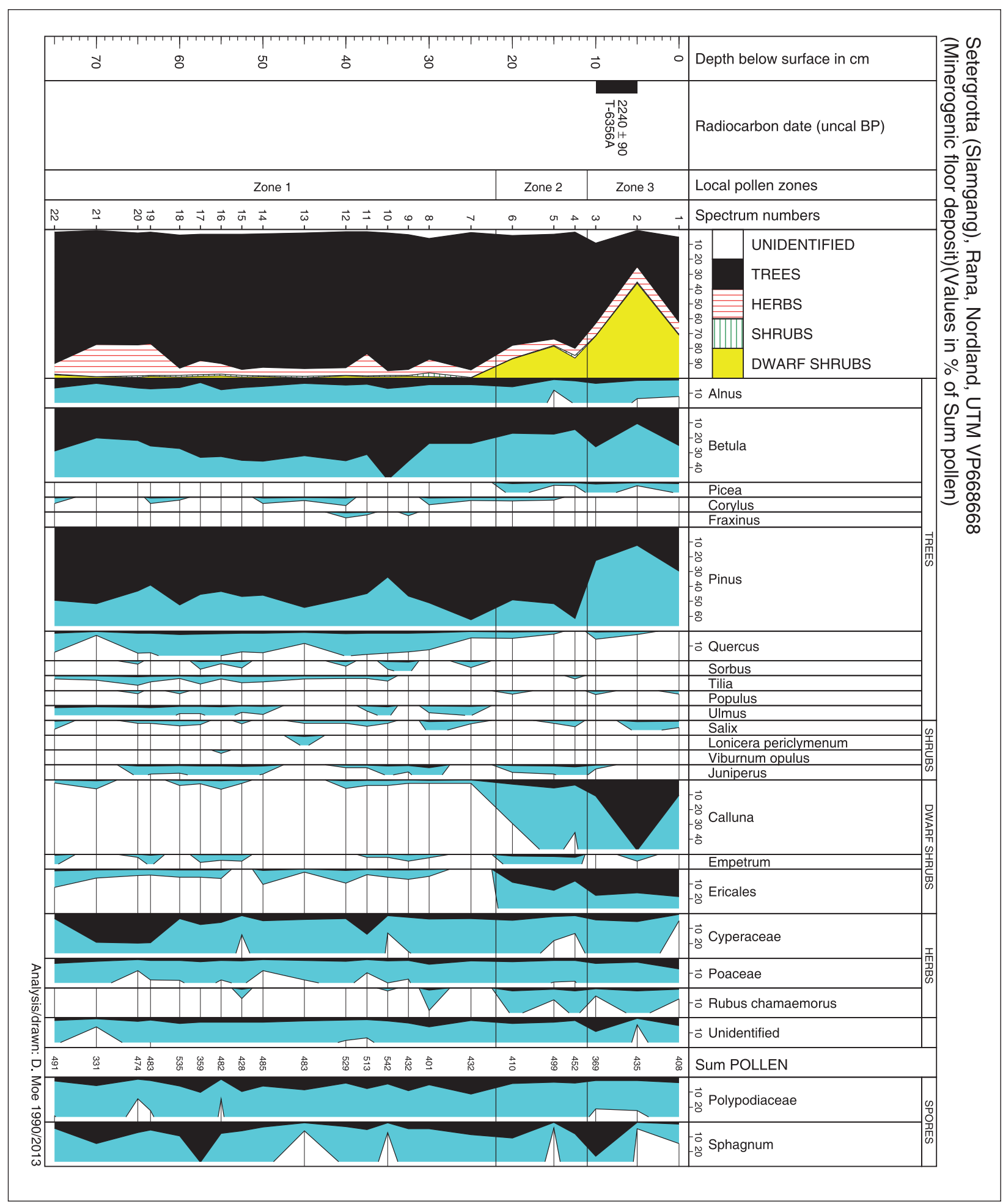

Fig. 2: Pollen diagram from parallel accretion the "Slamgang", Setergrotta. (Calculation in \% of total pollen.) 


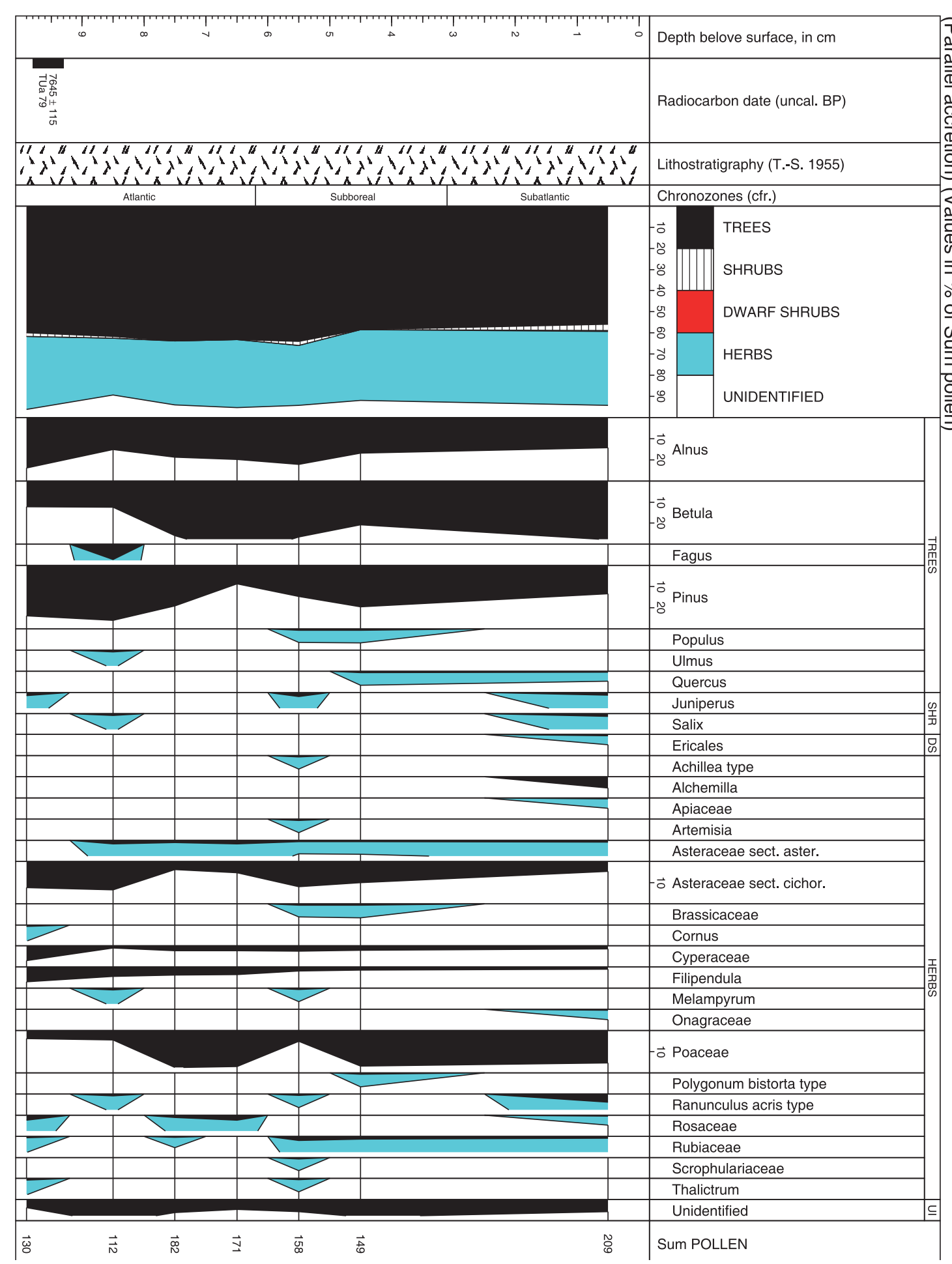




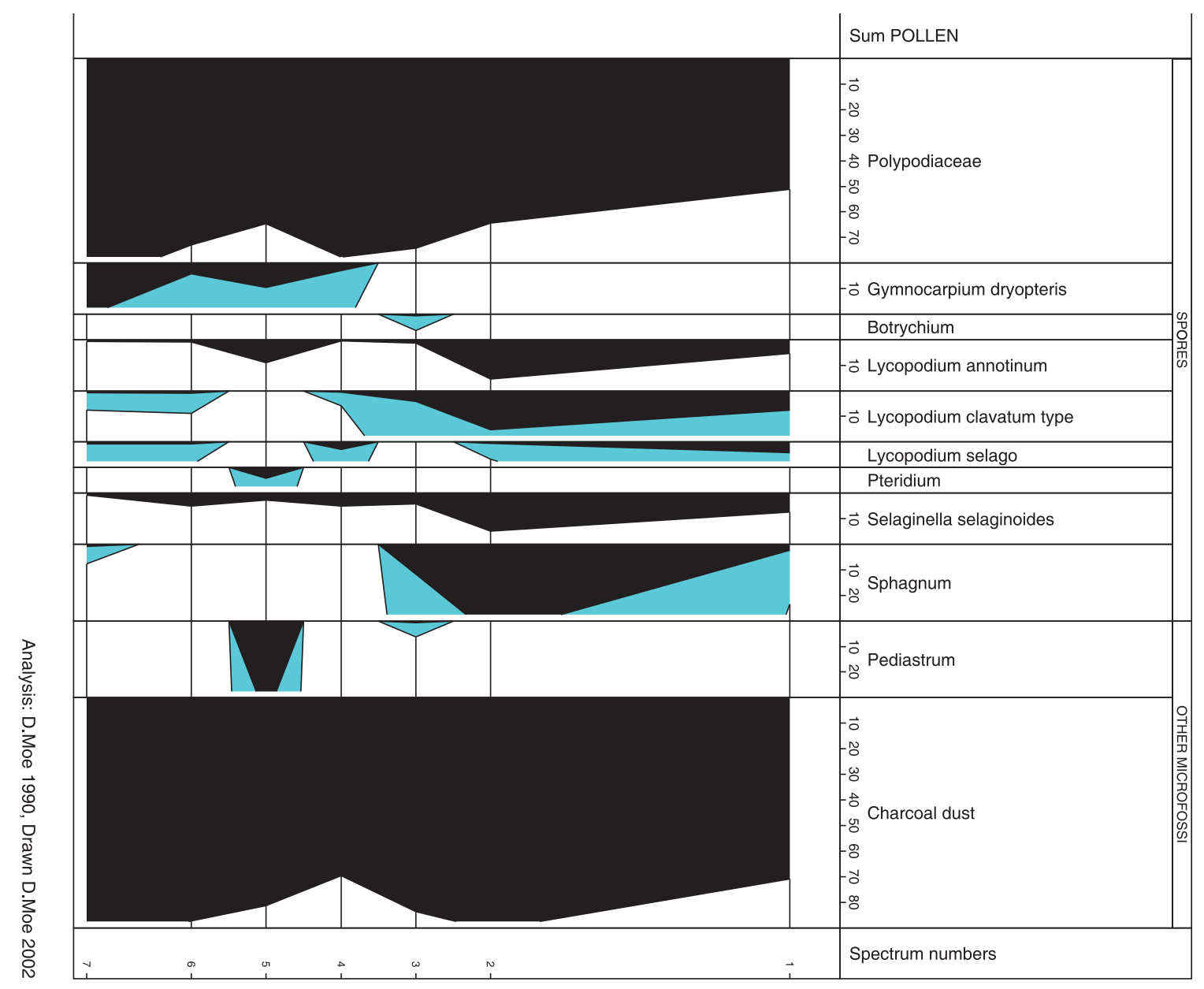

Fig. 3: Pollen diagram from the cave floor deposit the "Slamgang", Setergrotta. (Calculation in \% of total pollen.)

\section{DISCUSSION}

\section{THE DEVELOPMENT OF THE PARALLEL ACCRETION.}

The ${ }^{14} \mathrm{C}$ date, about $6800-6200 \mathrm{cal} . \mathrm{BC}(7645 \pm 115 \mathrm{BP})$ (Tab. 1), close to the roof reflect an early commencement (early Atlantic zone) of the organic deposition attached onto the nearly horizontal ceiling in the cave. The small ligneous pieces used for the date, reflect organic matter transported into the cave, and may be either primary or redeposited fragments from some older primary deposits outside the cave, or a mixture. In the first case, the accretion process may have started a little earlier than the date, or about the border between Boreal and Atlantic zone, or close to a general known climatic change for southwestern Norway (Moe 1995), - from continental to a more humid or perhaps oceanic climate regime. This also matches with Seppä \& Birks $(2001,2002)$ results. The accretion process in this cave need sufficient water supply, at least part of the year, and the initiation stage of this process therefore may correspond to this climatic change. Hiatus' are possible but not identified.

Some comments are however possible to make to the small changes in the diagram. The main tree constituents are Alnus, Betula and Pinus, while ferns together with Poaceae and Asteraceae dominate the herbs (Fig. 2). A tendency for increased pollen values of juniper (Juniperus communis), Salix and heather species (Ericales) is registered in the youngest part of the profile.

The high values of fern spores and pollen of $\mathrm{Al}$ nus throughout the profile need to reflect local alder, most likely grey alder (A. incana) in most of the period, 
probably growing nearby the actual waterway entering the cave. In Rana only A. incana in the genera has been registered in Holocene with immigration around 7200 $\mathrm{BC} / 6900 \mathrm{BC}$ with an increase around $5500 \mathrm{BC} / 1300$ $\mathrm{BC}$, especially in lime rich areas (Nilssen \& Vorren 1987).

The curve for bog moss (Sphagnum spp.), indicates local favourable humid conditions close to the drainage system connected to the cave during the last half part of the sequence. The amount of carbonised elements 'charcoal' in the Fig. 2 is high. One source for this type of particle coming into the cave is partly by water, often floating on the surface and later attached to the walls. Other sources are particles in the air masses passing through the cave system as a part of the draught effect (Lauritzen et al. 1990; Navarro et al. 2000, 2001), where charcoal dust, smaller in size, are frequent. Contrary to the coarser plant remains which have been transported by water into the cave, the charcoal particles were probably transported by the wind draft.

Pollen of elm (Ulmus glabra) is only found at one level at the oldest part of the diagram. The tree spreads its pollen rather badly, so local elm is possible (Moe 1998). The absence pollen of Ulmus in the surface spectrum does not necessarily reflect absence of elm, despite its growing not so far away. Elm immigrated to the Namdalen - Rana region, firstly in coastal areas around 6450 cal. BC (Nilssen \& Vorren 1987). After the first arrival, the real expansion took place about $4950 \mathrm{cal}$. BC and $5800 \mathrm{cal} \mathrm{BP}$. Later on, a retreat is dated to around AD 1. The absence of Ulmus pollen in the surface spectra, does not necessarily reflect an absence of elm, despite it is known to grow not so far away (e.g. Moe 1970, 1978, 1998; Nilssen \& Vorren 1987:16).

The different changes (mostly minor) seen in the diagram alone, are not significant for any vegetational historical conclusions, and may be explained as changes in from-time-to-time sources of the material attached to the roof or normal statistical variations. The smooth curves may be an effect of some mixed and redeposited material.

No pollen indicates redeposited material of preglacial age. Changing wind directions, vegetation and water flow may easily be important factors

The development of the cave floor sequence.

The radiocarbon date, about 540-280 cal. BC $(2240 \pm 90 \mathrm{BP})(\mathrm{Tab} .1)$, from between 5 to $10 \mathrm{~cm}$ from the top first of all inform us about a distinct change in the pollen dataset, from a pollen flora dominated by $\mathrm{Pi}$ nus to a pollen flora dominated by dwarf shrubs, heather (Calluna vulgaris), crowberry (Empetrum spp.) and other Ericales) (Fig. 3). Without any local parallel study outside the cave, it is difficult to say if this change also reflects a change in the real local vegetation. Traditional, similar changes dated to around the border between the Subboreal and Subatlanticum (500 BC) are found in several places, interpreted as partly a start of a climatic deterioration. However, increased human impact during this part of early Iron Age (e.g. Moe 1991, 2003) is likely with an initiating start in the profile some time before the border between zone 2 and 3 .

Occurrences of spruce (Picea abies) pollen are found in zone 2 upwards. The immigration of spruce is dated to around AD 600 - AD 800 in the Namdalen area, around AD 1500-1600 into the Rana region, and with a further spread during the last 500 years (Mørkved 1987). The low pollen values of Picea in zone 2 need to reflect some kind of long distant transport from the east, while the pollen in zone 3 probably are of more local origin (Moe 1970)

The high values of fern spores (Polypodiaceae) and pollen of alder (A. incana) throughout the profile need to reflect local growth, of alder most likely grey alder growing nearby the actual waterway entering the cave. Among the actual species only A. incana has been registered in Holocene with immigration around $6950 \mathrm{BC}$ with an increase around 5050 BC-1250 BC, especially in lime rich areas (Nilssen \& Vorren 1987:15).

\section{CONCLUSION}

The two radiocarbon dates indicate organic deposition of Holocene age. The radiocarbon date from parallel accretion should be used with great care; even in our case only one small piece of wood is used. The actual ${ }^{14} \mathrm{C}$ date gives, however, a minimum age of the commencement of the parallel accretion which, in this case was at the border between the Boreal and Atlanticum chronozones (Mangerud et al. 1974).
It is possible that the two sediments have been developed during the same time.

The occurrence of parallel accretion is not previously described for this area. The accumulation up to about $10 \mathrm{~cm}$ in thickness of organic matter upside-down in the cave Setergrotta is however striking. Pollen and spores together with coarser organic debris have followed the water for a primary deposit or redeposit. It is suggested 
that pollen, spores, and also charcoal have been transported into the cave system by water, also floating on water, and by wind draught through the air.

The development of the accretion deposit needs to have been dependent on water level filling the tunnel system during parts of the year, probably during the spring snow-melt season with high discharges in rivers and creeks.

Presence of Betula, Alnus and Pinus through most of the two diagrams indicate woodland vegetation dominated by these taxa. The very high value of charcoal in the parallel accretion sequence inside the cave does not indicate a higher human activity inside the cave in former time; it rather reflects a perfect trapping system for minor particles within rather than outside a cave-system (Lauritzen et al. 1990).

The pollen analytical study based on the material from the parallel accretion is neither useful for palaeo- ecological information and evaluations of the local vegetation outside the cave system, nor for climatic studies, since material of different ages may have been mixed.

The changes in the pollen frequency curves in the parallel accretion are weak and the resolution quite low, and the dataset hardly gives any palaeoecological information at all.

The cave floor sediment, however, seems to reflect a much more significant vegetation development than the accretion sequence. The resolution is better and the vegetation changes, at least in the youngest parts are similar to what is found in traditional vegetation historical studies. The immigration of spruce (Picea) in the younger part follows known pattern.

The cave floor deposit reflects a distinct deforestation about $500 \mathrm{cal}$. BC. Human interference is possible and cannot be excluded.

\section{ACKNOWLEDGEMENTS}

Field and laboratory work was financed by the Olaf Grolle Olsen's Fund (University of Bergen). A special thanks to Vedis Bjørndal for the linguistic revision.

\section{REFERENCES}

Atkinson, T.C., 1985: Present and future directions in karst hydrogeology.- Annales de la Societé Geologique de Belgue, 108, 293-296.

Bui-Thi-Mai, M., 1974: Contribution à l'étude du transport et de la sédimentation des pluies polliniques dans un abri sous-roche, l'Abri Vaufrey (Dordogne).- L'Université de Bordeaux, Thesis (31/4e cycle). Biologie Vegetale, 1155, pp. 167.

Bui-Thi-Mai, M., 1988: Transport et sédimentation des pluies polliniques actuelles dans un abri-sous-roche: La Grotte Vaufrey (1).- In: J.-P. Rigaud (ed.) La Grotte Vaufrey. Paléoenvironement - Chronologie Activités, humaines, 65-74. Mémoires de la Société Préhistorique Française, tome XIX.

Ford, D.C. \& P.W. Williams, 2007: Karst Hydrogeology and Geomorphology.- Wiley, pp. 576, Chichester, U.K., http://dx.doi.org/10.1002/9781118684986

Fægri, K. \& J. Iversen, 1989: Textbook of pollen analysis. ( $4^{\text {th }}$ ed.).- John Wiley \& Sons, pp. 328, Chichester.
Hestangen, H., 2005: The sedimentology of the GrønliSetergrotta cave system, Mo i Rana, Nordland, Norway. Master. Department of Earth Science. University of Bergen.

Lauritzen, S.-E., Hestangen, H., Skutlaberg, S.M., \& R. Øvrevik Skoglund, 2005: The Grønli-Seter project, Rana, North Norway.- Proceedings of the 14th International Congress of Speleology, 21-28 August 2005, Athens, Kalamos, Hellas, Vol. 2, 609-613. (Poster).

Lauritzen, S.-E., Løvlie, R., Moe, D., \& E. Østbye, 1990: Palaeoclimate deduced from a multidisciplinary study of a half-million-year-old stalagmite from Rana.- Quaternary Research, 34, 306-316. http:// dx.doi.org/10.1016/0033-5894(90)90043-k

Mangin, A., 1975: Contribution a l'étude hydrodynamique des aquifères karstiques.

Troisieme partie: Constitution et fonctionnement des aquifères karstiques.- Annales de Spéléologie, 30, 21-124. 
Mangerud, J., Andersen, S.T., Berglund, B.E., \& J.J. Donner, 1974: Quaternary stratigraphy of Norden, a proposal for terminology and classification.- Boreas, 3, 109-128. http://dx.doi.org/10.1111/j.15023885.1974.tb00669.x

Moe, D., 1970: A pollen analysis of an occurrence of elm in Beiarn, Nordland county, northern Norway.University of Bergen, Mat. naturv. ser. 2, pp. 21.

Moe, D., 1978: Studier over vegetasjonsutviklingen gjennom Holocen på Hardangervidda, Sør-Norge. II. Generell utvikling og tregrensevariasjoner.- University of Bergen, part of dr. Thesis, pp. 97.

Moe, D., 1991: Hustad, Arstad and Naurstad. A vegetational study of three farms in Salten, North Norway.-.- Norsk geografisk tidsskrift, 45, 11-24. http:// dx.doi.org/10.1080/00291959108621977

Moe, D., 1995: Climatic variations in western Norway during the last 13,000 years. A review.- Geologija, (Vilnius), (1994) 17, 159-165.

Moe, D., 1998: Contribution to the history of the Holocene distribution of Ulmus glabra in North Norway.- Norsk Geografisk tidsskrift, 52, 57-63. http:// dx.doi.org/10.1080/00291959808552385

Moe, D., 2003: Landscape history and heathland development over the last 4000 years in the Bodø area, northern Norway.- Norsk geografisk tidsskrift/ Norwegian Journal of Geography 57, 4-11. http:// dx.doi.org/10.1080/00291950310003070

Mørkved, B., 1987: Granskogens historie i Nord-Norge.In: Sveli, A. (ed.) Skogbruk i Nord-Norge - streiftog gjennom historien (:24-30).- Nord-Norges skogsmannsforbund. Rønnes Trykk, Mosjøen. pp. 504.

Navarro, C., Carrión, J.S., Munuera, M. \& A.R. Prieto, 2001: Cave surface pollen and the palynological potential of karstic cave sediments in Palaeoecology.- Review of Palaeobotany and Palynology, 117, 245-265. http:// dx.doi.org/10.1016/s0034-6667(01)00095-1

Navarro, C., Carrión, J.S., Navarro, Munuera, M. \& A.R. Prieto, 2000: An experimental approach to the palynology of cave deposits.- Journal of Quaternary Science, 15, 6, 603-619. http://dx.doi.org/10.1002/10991417(200009)15:6<603::aid-jqs544>3.0.co;2-f

Nilssen, E. \& K.D. Vorren, 1987: Skogens innvandringshistorie. Skogstroers og noen buskveksters innvandring i Nord-Norge.- In: Sveli, A. (ed.) Skogbruk i NordNorge - streiftog gjennom historien pp. 11-23.Nord-Norges skogsmannsforbund. Rønnes Trykk, Mosjøen. pp. 504.

NVE, 2002: Runoff map of Norway, sheet 5, scale 1:500,000.- Norges vassdrags- og energidirektorat.

Reams, M.W., 1968: Cave sediments and the geomorphic history of the Ozarks.- Washington University, PhD thesis, Saint Louis, Missouri, pp. 167.
Reimer, P.J., E. Bard, A. Bayliss, J.W. Beck, P.G. Blackwell, C. Bronk Ramsey, P.M. Grootes, T.P. Guilderson, H. Haflidason, I. Hajdas, C. Hatt, T.J. Heaton, D.L. Hoffmann, A.G. Hogg, K.A. Hughen, K.F. Kaiser, B. Kromer, S.W. Manning, M. Niu, R.W. Reimer, D.A. Richards, E.M. Scott, J.R. Southon, R.A. Staff, C.S.M. Turney \& J. van der Plicht, 2013: IntCal13 and Marine13. Radiocarbon Age Calibration Curves 0-50,000 Years cal BP.- Radiocarbon, 55(4). http://dx.doi.org/10.2458/azu_js_rc.55.16947

Seppä, H. \& H.J.B. Birks, 2001: July mean temperature and annual precipitation trends during the Holocene in the Fennoscandian tree-line area: pollen-based climate reconstructions.- The Holocene 11(5), 527-539. http://dx.doi. org/10.1191/095968301680223486

Seppä, H. \& H.J.B. Birks, 2002: Holocene climate reconstructions from the Fennoscandian tree-line area based on pollen data from Toskaljavri.- Quaternary Research, 57, 191-199. http://dx.doi.org/10.1006/ qres.2001.2313

Skoglund, R.Ø. \& S.-E. Lauritzen, 2013: Characterisation of a post-glacial invasion aquifer: the Grønli-Seter karst system, northern Norway.- Norwegian Journal of Geology, 93, 61-73.

Skutlaberg, S., 2003: Paleohydrogeologi, bruddgeometri og litostratigrafi i Grønli-Setergrottesystemet, Mo i Rana.- Department of Earth Science. University of Bergen.

St. Pierre, S., 1988: Morphology and sediments of the Grønli - Seter Caves, Norway.- Cave Science, 15, $109-116$

Stephens, M.B., Gustavson, M., Ramberg, I.B. \& E. Zachrisson, 1985: The Caledonides of central-north Scandinavia - a tectonostratigraphic overview.- In: The Caledonide Orogen - Scandinavia and Related Areas (Gee, D.G. \& B.A. Sturt (eds.)). John Wiley \& Sons Ltd.

Søvegjarto, U., Marker, M. \& S. Gjelle, 1989: Storforshei 2027 IV, berggrunnskart, M 1:50 000.- Norges Geologiske Undersøkelse.

Troels-Smith, J., 1955: Characterisation of unconsolidated sediments.- Danmarks geol. Undersøgelser, 4, 3, $1-73$.

Østbye E., Lauritzen, S.-E., Moe, D. \& K. Østbye, 2006: Vertebrate remains in Holocene limestone cave sediments: faunal succession in the Sirijorda Cave, northern Norway.- Boreas, 35, 142-158. http:// dx.doi.org/10.1080/03009480500359129

Øvrevik, R., 2002: Hydrogeologi og karstkorrosjon i Grønli-Seterakviferen, Mo i Rana.- Master. Department of geology. University of Bergen. 